\title{
Extracellular matrix protein Big-h3/TGFBI promotes metastasis of colon cancer by enhancing cell extravasation
}

\author{
Chaoyu Ma, ${ }^{1}$ Yu Rong, ${ }^{1}$ Daniel R. Radiloff, ${ }^{1}$ Michael B. Datto, ${ }^{2}$ Barbara Centeno, ${ }^{3}$ Shideng Bao, ${ }^{4}$ \\ Anthony Wai Ming Cheng, ${ }^{2}$ Fumin Lin, ${ }^{1}$ Shibo Jiang, ${ }^{5}$ Timothy J. Yeatman, ${ }^{3}$ and Xiao-Fan Wang ${ }^{1,6}$ \\ ${ }^{1}$ Department of Pharmacology and Cancer Biology, Duke University Medical Center, Durham, North Carolina 27710, USA; \\ ${ }^{2}$ Department of Pathology, Duke University Medical Center, Durham, North Carolina 27710, USA; ${ }^{3}$ Department of Surgery, \\ H. Lee Moffitt Cancer Center and Research Institute, Tampa, Florida 33612, USA; ${ }^{4}$ Department of Radiation Oncology and \\ Department of Neurosurgery, University of Colorado at Denver and Health Science Center, Aurora, Colorado 80045, USA; \\ ${ }^{5}$ Lindsley F. Kimball Research Institute, New York Blood Center, New York, New York 10021, USA
}

\begin{abstract}
Metastasis, the major cause of cancer death, is a multistep process that requires interactions between cancer cells and stromal cells and between cancer cells and extracellular matrix. Molecular alterations of the extracellular matrix in the tumor microenvironment have a considerable impact on the metastatic process during tumorigenesis. Here we report that elevated expression of $\beta$ ig-h3/TGFBI (transforming growth factor, $\beta$-induced), an extracellular matrix protein secreted by colon cancer cells, is associated with high-grade human colon cancers. Ectopic expression of the $\beta i g-h 3$ protein enhanced the aggressiveness and altered the metastatic properties of colon cancer cells in vivo. Inhibition of $\beta$ ig-h3 expression dramatically reduced metastasis. Mechanistically, $\beta$ ig-h3 appears to promote extravasation, a critical step in the metastatic dissemination of cancer cells, by inducing the dissociation of VE-cadherin junctions between endothelial cells via activation of the integrin $\alpha_{v} \beta_{5}-$ Src signaling pathway. Thus, cancers associated with overexpression of $\beta i g-h 3$ may have an increased metastatic potential, leading to poor prognosis in cancer patients.
\end{abstract}

[Keywords: $\beta$ ig-h3/TGFBI; extravasation; metastasis; extracellular matrix; colon cancer; integrin $\alpha_{\mathrm{v}} \beta_{5}$ ]

Supplemental material is available at http://www.genesdev.org.

Received November 7, 2007; revised version accepted December 6, 2007.

Tumor metastasis consists of a series of complex steps, all of which must be successfully completed to give rise to clinically detectable metastatic tumors at distal organs (Woodhouse et al. 1997; Hanahan and Weinberg 2000; Chambers et al. 2002; Bierie and Moses 2006; Gomis et al. 2006). To complete the journey, primary cancer cells have to invade through the basement membrane, intravasate into the bloodstream, disseminate through the circulation, and extravasate to distal tissues/organs. The entire process, regulated by interactions between cancer cells and stromal cells and between cancer cells and extracellular matrix (ECM), remains poorly understood at the level of molecular mechanism.

Extravasation, the process by which tumor cells leave a blood or lymphatic vessel and invade the surrounding tissue parenchyma, requires dynamic interaction between cancer cells and endothelial cells lining the blood

${ }^{6}$ Corresponding author.

E-MAIL wang0011@mc.duke.edu; FAX (919) 681-7152.

Article is online at http://www.genesdev.org/cgi/doi/10.1101/gad.1632008. vessel wall (Weiss 1990; Chambers et al. 2002; MacDonald et al. 2002; Weis and Cheresh 2005). As a major component of the tumor microenvironment, ECM proteins secreted by cancer and/or stromal cells potentially affect the dissemination process through modulation of the interaction between cancer and endothelial cells (Bernstein and Liotta 1994). Recently, large-scale analyses of gene expression profiles of human cancers have revealed that aberrant expression patterns of ECM proteins are common among a wide range of cancer types (Buckhaults et al. 2001; Cooper et al. 2003), suggesting that alterations in the expression profiles of ECM proteins during tumor development can consequently exert a functional impact on the metastatic process, including extravasation (Gupta et al. 2007; Karnoub et al. 2007).

Previously we demonstrated that periostin, a secreted ECM protein that is overexpressed by several cancer types, promotes tumor angiogenesis and metastasis (Bao et al. 2004; Shao et al. 2004). ßig-h3/TGFBI (transforming growth factor, $\beta$-induced; hereinafter referred to as $\beta$ ig$\mathrm{h} 3$ ), a structural homolog of periostin, was found by se- 
rial analysis of gene expression (SAGE) to be one of the genes that are highly elevated in various types of cancers (Zhang et al. 1997; Argani et al. 2001). ßig-h3 contains an $\mathrm{N}$-terminal secretory signal peptide, followed by a cysteine-rich domain, four internal homologous repeats (FAS1 domain), and a C-terminal RGD motif (Supplemental Fig. S1; Skonier et al. 1992). The FAS1 domain of ßig-h3 shares high homology with fasciclin I, an axon guidance protein that is involved in neural development in invertebrates (Bastiani et al. 1987). Normally, the expression of $\beta$ ig-h3 is mainly found in fibroblasts, keratinocytes, and muscle cells (LeBaron et al. 1995; Bae et al. 2002; Ferguson et al. 2003). The physiological function of $\beta$ ig-h3 has been postulated to be involved in cellmatrix interaction and cell migration (Bae et al. 2002; Kim et al. 2003), and Big-h3 overexpression has been associated with atherosclerotic and restenotic vascular lesions in humans (O'Brien et al. 1996; Lee et al. 2006). In this report, we demonstrate that acquired expression of $\beta$ ig-h3 by colon cancer cells leads to a more aggressive phenotype of metastasis. ßig-h3 induces the dissociation of VE-cadherin junctions between endothelial cells via the integrin $\alpha_{v} \beta_{5}-$ Src signaling pathway, which results in enhanced cancer cell extravasation.

\section{Results}

Big-h3 expression is up-regulated in human colon cancers

Previous studies using the SAGE strategy have revealed that TGFBI expression is substantially elevated in colon and pancreatic cancers in comparison with corresponding normal tissues (representative results are summarized in Supplemental Table S1). Several subsequent studies using gene array analyses have also demonstrated that TGFBI is overexpressed in a majority of tumor samples in comparison with their normal tissue counterparts in colorectal cancer patients (summarized in Supplemental Table S2). To further confirm the association between human colon cancer and $\beta$ ig-h3 overexpression, we conducted a survey of $\beta$ ig-h3 expression using immunohistochemical staining of tissue microarray (TMA) samples derived from the colon tissue of $66 \mathrm{pa}-$ tients. $\beta$ ig-h3 overexpression was more frequent in highgrade (Stage III and IV) tumors $(32.2 \%, n=31)$ than in low-grade (Stage I and II) tumors $(18.5 \%, n=27)$, whereas no $\beta$ ig-h3 expression was detected in the normal epithelial tissues $(n=8)$ (Fig. 1A,B). Furthermore, $\beta$ ig-h3 overexpression is closely correlated with high-grade tumors derived from patients who were metastatic-prone or had already developed metastatic disease, indicating that high levels of Big-h3 may be associated with the metastatic process. (Information on patients from whom tumor samples were found with high expression levels of $\beta i g$-h3 protein is summarized in Supplemental Tables S3, S4.)

Overexpression of $\beta$ ig-h3 in colon cancer cells promotes tumor metastasis in vivo

To study the functional role of $\beta$ ig-h3 overexpression in colon cancer development, we used a model system con- sisting of two colon cancer cell lines, SW480 and SW620, derived from the primary tumor and lymph node metastasis of the same patient, respectively (Leibovitz et al. 1976). Previous studies with xenograft tumor growth in immunocompromised mice showed that the primary tumor-derived SW480 cell line exhibits a limited metastatic potential, whereas the lymph node metastasis-derived SW620 cell line displays an aggressive metastatic pattern (Hewitt et al. 2000). Importantly to this study, the two cell lines exhibit a different $\beta$ ig-h3 expression profile (Fig. 1C). To determine whether the difference in ßig-h3 expression might be one of the reasons underlying the different metastatic potentials of this isogenic pair of cell lines, we stably expressed $\beta$ ig-h3 in the poorly metastatic SW480 cells to a level comparable with that of the aggressively metastatic SW620 cells (Fig. 1C). Equal numbers of SW480-ßig-h3 or SW480-VEC control cells were then injected intravenously via the tail vein into 20 SCID-Beige mice, respectively. Twelve weeks after inoculation of the tumor cells, mice were sacrificed and examined for metastases in the lung and other organs. As shown in Figure 1, D and E, metastatic growth was easily detected in the lungs of all 20 mice injected with SW480Big-h3 cells. A majority of these animals bore large numbers of tumors covering almost the entire lung. In contrast, only nine out of 20 mice injected with the SW480VEC cells developed a small number of tumor nodules in the lung (Fig. 1D,E). The average number of visible metastatic nodules increased from $1.6 \pm 2.1$ per lung in mice carrying SW480-VEC control tumors to $23.2 \pm 11.6$ per

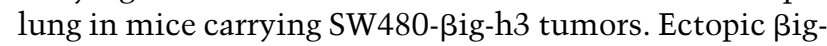
h3 expression remained present in the metastatic tumors, which was confirmed by immunohistochemical staining (Fig. 1F). Interestingly, however, there was no significant difference in the average size of the metastatic tumors derived from the SW480- $\beta$ ig-h3 and SW480-VEC cells (Supplemental Fig. S2A; Supplemental Table S5). This suggests that $\beta$ ig-h3 expression in the SW480 cells significantly increased the probability of metastatic colonization in the lung without affecting the growth rate of metastasized tumors. Overall, our data suggest that $\beta$ ig-h3 overexpression is sufficient to promote the metastatic potential of colon cancer cell line SW480 in vivo.

Suppression of $\beta$ ig-h3 expression in SW620 cells significantly decreases their metastatic potential in vivo

We next performed loss-of-function experiments to test whether $\beta$ ig-h3 expression is required for the metastatic potential of the aggressive isogenic line of SW620 cells. We designed two shRNA sequences targeting different coding regions of the $\beta$ ig-h3 gene. Stable expression of the shRNA constructs considerably reduced the expression level of $\beta$ ig-h3 protein in the populations of SW620 cells (Fig. 2A). Equal numbers of the shRNA-expressing or vector-control SW620 cells were each intravenously injected into SCID-Beige mice via the tail vein. Seven weeks after inoculation, the SW620-VEC control cells formed a large number of tumor nodules in the lung (Fig. 
Figure 1. Elevated $\beta$ ig-h3 expression is associated with high-grade colon cancers and an impact on metastasis of colon cancer cells. (A) Immunohistochemical analysis of $\beta$ ig-h 3 expression in colon cancers. The tissue sections were immunostained with an anti- $\beta$ ig-h 3 polyclonal antibody. The positive staining for $\beta$ ig-h3 protein is shown in a reddish-brown color. All sections were counterstained with hematoxylin showing a blue color. (Panel $a$ ) Normal colon mucosa (N), stroma (S), and epithelia (E). (Panel $b$ ) Adenomatous polyps (AP). (Panel c) Stage II colon adenocarcinoma ( $\mathrm{T}$ II). (Panel $d$ ) Stage IV poorly differentiated colon adenocarcinoma (T IV). (B) The percentage of tissue samples with $\beta$ ig-h3 protein overexpression was plotted according to the malignant stage of the patient. Statistical analysis indicated that the highgrade tumors have a significantly higher ratio to associate with $\beta$ ig-h3 overexpression as compared with low-grade tumors $\left(\left[{ }^{\star}\right] P=0.026\right)$ and normal tissues $\left(\left[{ }^{\star \star}\right]\right.$ $P=0.0035) .(C)$ Expression pattern of $\beta$ igh3 in SW480 and SW620 cells. SW480 cells (parental) were infected with recombinant retroviruses containing either vector control (VEC) or $\beta$ ig-h3 full-length cDNA tagged with the Flag-epitope ( $\beta$ ig-h3). An equal amount of concentrated supernatant from each cell type as indicated was examined for the presence of $\beta$ ig-h3 by Western blot using an anti- $\beta$ ig-h3 or anti-Flag antibody. The whole-cell lysate from each sample of cells from which the supernatant was collected for the determination of ßig-h3 expression was blotted with antitubulin antibody for loading control. $(D)$ Representative results showing the formation of metastases in the lung of mice injected with SW480-VEC cells (C1, C2) and SW480- $\beta$ ig-h3 cells (T1, T2). We injected $4 \times 10^{6}$ SW480-VEC or SW480- $\beta$ ig-h3 cells through the tail vein into 5 -wk-old SCIDBeige mice with five mice for each group.

A
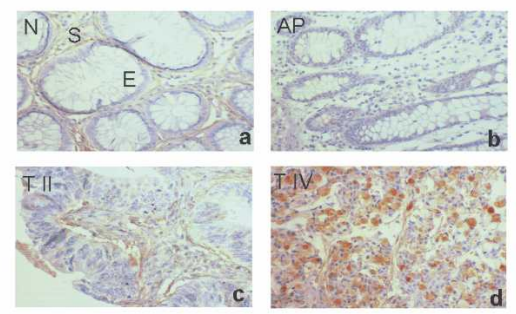

B

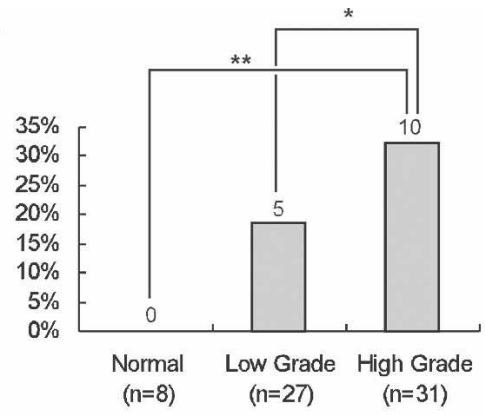

C

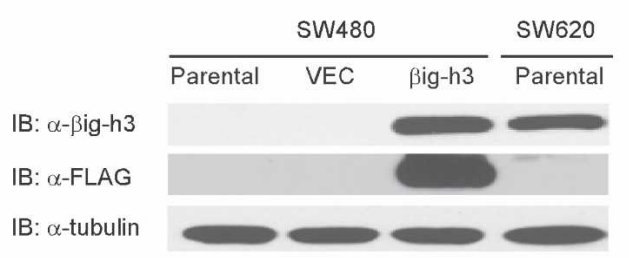

D

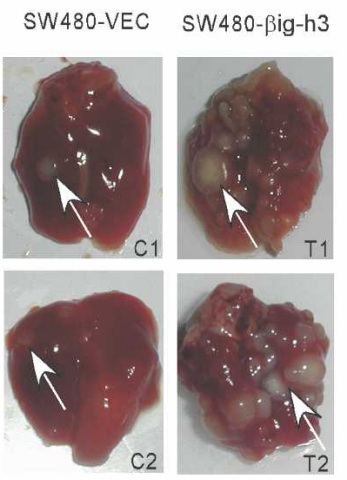

E

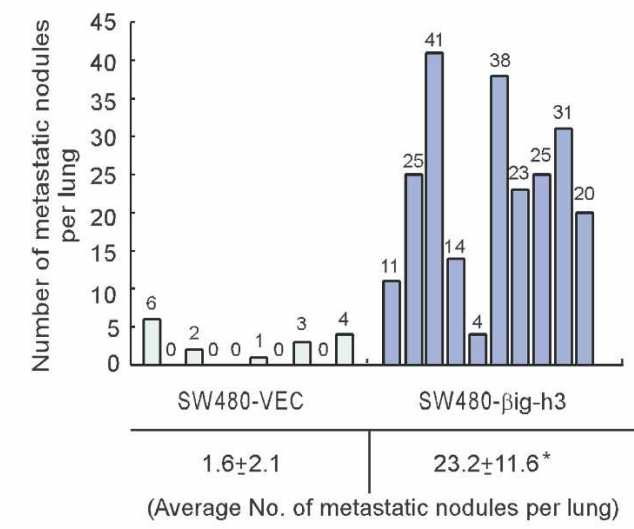

$\mathrm{F}$ SW480-VEC

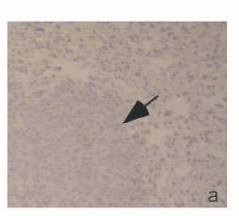

Big-h3 Staining

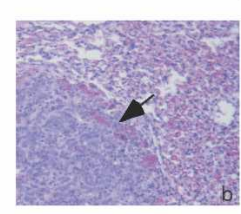

H\&E Staining

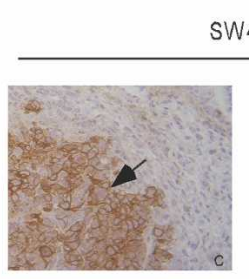

Big-h3 Staining
SW480- $\beta$ ig-h3

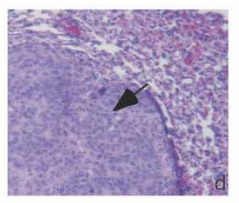

H\&E Staining

Mice were sacrificed and examined for the growth of metastatic tumors $12 \mathrm{wk}$ after injection. Four independent experiments were performed. Arrows indicate metastatic tumors in the mouse lung. $(E)$ Representative results from two independent experiments showing total numbers of lung metastatic nodules in individual mouse injected with SW480-VEC or SW480- $\beta$ ig-h3 cells. The counting was performed under a dissection scope. $\left({ }^{*}\right) P<0.01(n=10) .(F)$ Immunohistochemical staining with paraffin-embedded sections of lung tissues isolated from mice intravenously inoculated with SW480-VEC or SW480- $\beta$ ig-h3 cells. (Panels $a, c)$ Paraffin-embedded sections stained for the presence of $\beta$ ig-h3 in tumors derived from SW480-VEC cells (panel $a$ ) and SW480- $\beta$ ig-h3 cells (panel $c$ ). Positive staining is depicted in brown color. (Panels $b, d)$ Hematoxylin/eosin staining for sections derived from SW480-VEC cells (panel $b$ ) and SW480- $\beta$ ig-h3 cells (panel $d$ ). Arrows indicate tumors in the mouse lung.

2C,D). In addition, the SW620-VEC control cells also formed tumor masses derived from lymph nodes around bilateral axillary and lateral thoracic regions, which had migrated to the back of the animals (Fig. 2B,D). In sharp

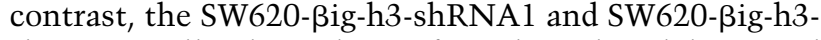
shRNA2 cells showed significantly reduced lung and lymph node metastasis (Fig. 2B-D). Furthermore, all mice injected with SW620-VEC cells (10 of 10) also had adrenal gland and mesentery metastasis, which was seen in only $20 \%$ (two of 10 ) of the mice injected with the ßig-h3 knockdown cells (representative results are shown in Supplemental Fig. S3). Again, the average size of each metastatic tumor colony in the lung was comparable for the SW620-VEC and SW620-Big-h3-shRNA cells (Supplemental Fig. S2B; Supplemental Table S6), supporting the assumption that $\beta$ ig-h 3 expression affects 
A

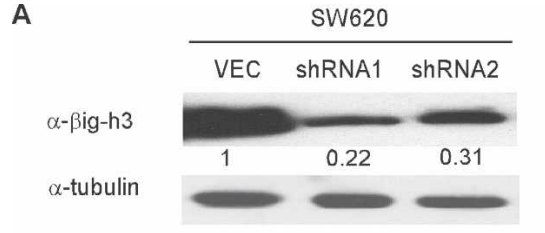

C

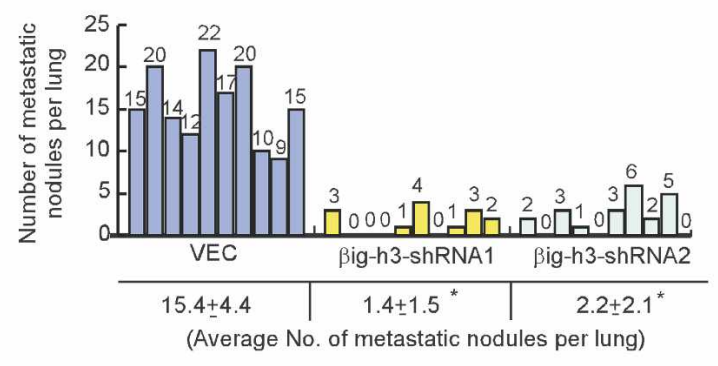

D

Lung \& outside chest cavity

Back

B

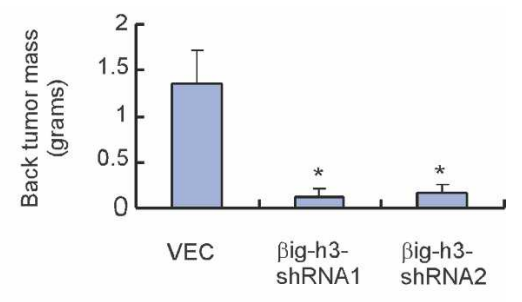

Figure 2. Reduction in the expression level of $\beta$ ig-h3 in SW620 colon cancer cells inhibits metastasis in vivo. $(A)$ The expression level of $\beta$ ig-h3 in SW620 cells was reduced by $78 \%$ and $69 \%$, respectively, using two different shRNA constructs. SW620 cells (parental) were infected with recombinant retroviruses containing vector control (VEC), shRNA1 (ßig-h3-shRNA1), or shRNA2 (ßig-h3-shRNA2). An equal amount of concentrated supernatant from each cell type as indicated was examined for the presence of $\beta$ ig-h3 by Western blot

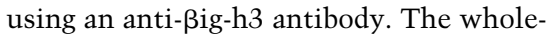
cell lysate from each sample of cells from which the supernatant was collected for the determination of $\beta$ ig-h3 expression was blotted with anti-tubulin antibody for loading control. (B) Reduced Big-h3 expression led to decreases in tumor formation on the back of mice by the SW620 cells. We injected $2 \times 10^{6}$ SW620-VEC, SW620-

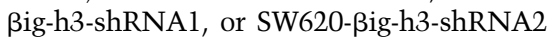
cells through the tail vein into 5-wk-old SCID-Beige mice with five animals for each group. Mice were sacrificed and examined for the growth of metastatic tumors 7 wk after injection. Results are the mean \pm SD of five animals from each group. Four independent experiments

were performed. $\left(^{\star}\right) P<0.01(n=5) .(C)$ Representative results from two independent experiments showing total numbers of lung

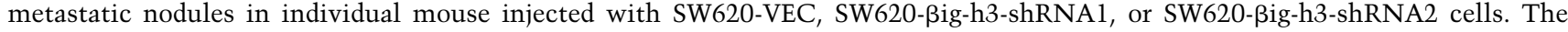
counting was performed under the dissection scope. $\left({ }^{\star}\right) P<0.01(n=10)$. $(D)$ Representative results showing that injection of SW620-

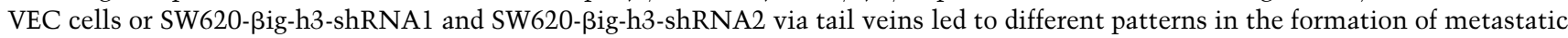
tumors.

primarily the number of metastatic colonies without changing the size of each colony.

To validate these results, we conducted a rescue experiment to exclude any possibility of an off-target effect associated with the shRNA approach. An shRNA-resistant $\beta$ ig-h3 gene ( $\beta$ ig-h3n) was expressed in SW620shRNA1 cells to a level that was 1.67-fold higher than the endogenous level of $\beta$ ig-h3 in the parental SW620 cells transfected with a control vector (Fig. 3A). Surprisingly, merely 4 wk after tail vein injection, the SW620$\beta$ ig-h $3 \mathrm{n}$ cells were already detected inside the skull, in adrenal glands and the lymph nodes (Fig. 3B-E). At this time point, no tumor masses were detected in any of the mice inoculated with the control SW620-VEC cells, suggesting that a further increase in the level of $\beta$ ig-h3 expression in SW620 cells led to an even more aggressive metastatic phenotype. Together, all these data from the tail vein injection experiments strongly suggest that the level of $\beta$ ig-h3 expression dictates the aggressiveness of SW620 colon cancer cells.

To further confirm the role of $\beta$ ig-h3 in the metastatic process, we examined the tumor cell metastasis in mice following intracardiac injection (Yin et al. 1999). Consistent with the previous intravenous injection experiments, SW620 or SW480 cancer cells with higher levels of $\beta$ ig-h3 expression displayed a more aggressive behav- ior in forming metastatic colonies in distal organs, such as adrenal gland, bone, and mesentery, when compared with their paired control tumor cells with lower levels of Big-h3 expression (Fig. 3F-H). Taken together, these results support the notion that $\beta$ ig-h3, when acquired or overexpressed, has a profound impact on the formation of tumor metastasis by the colon cancer cells.

Big-h3 promotes trans-endothelial cell migration (TEM) in vitro by inducing VE-cadherin junction dissociation in the endothelial monolayer

To explore the mechanism by which $\beta$ ig-h3 expression has an impact on metastasis, we performed a series of in vitro functional assays. In our previous studies, we showed that periostin enhances tumor metastasis by promoting both angiogenesis and cell survival (Bao et al. 2004; Shao et al. 2004). Since $\beta i g-h 3$ shares significant structural homology with periostin (Supplemental Fig. S1; Skonier et al. 1992; Horiuchi et al. 1999) and both proteins play positive roles in tumor metastatic progression, we examined if $\beta$ ig-h3 has the same effects on tumor cells. Unlike periostin, however, $\beta$ ig-h3 showed no effect on cell survival under hypoxic conditions and failed to rescue the anoikis-induced apoptosis of the cancer cells (Supplemental Fig. S4). On the other hand, blood 
Ma et al.
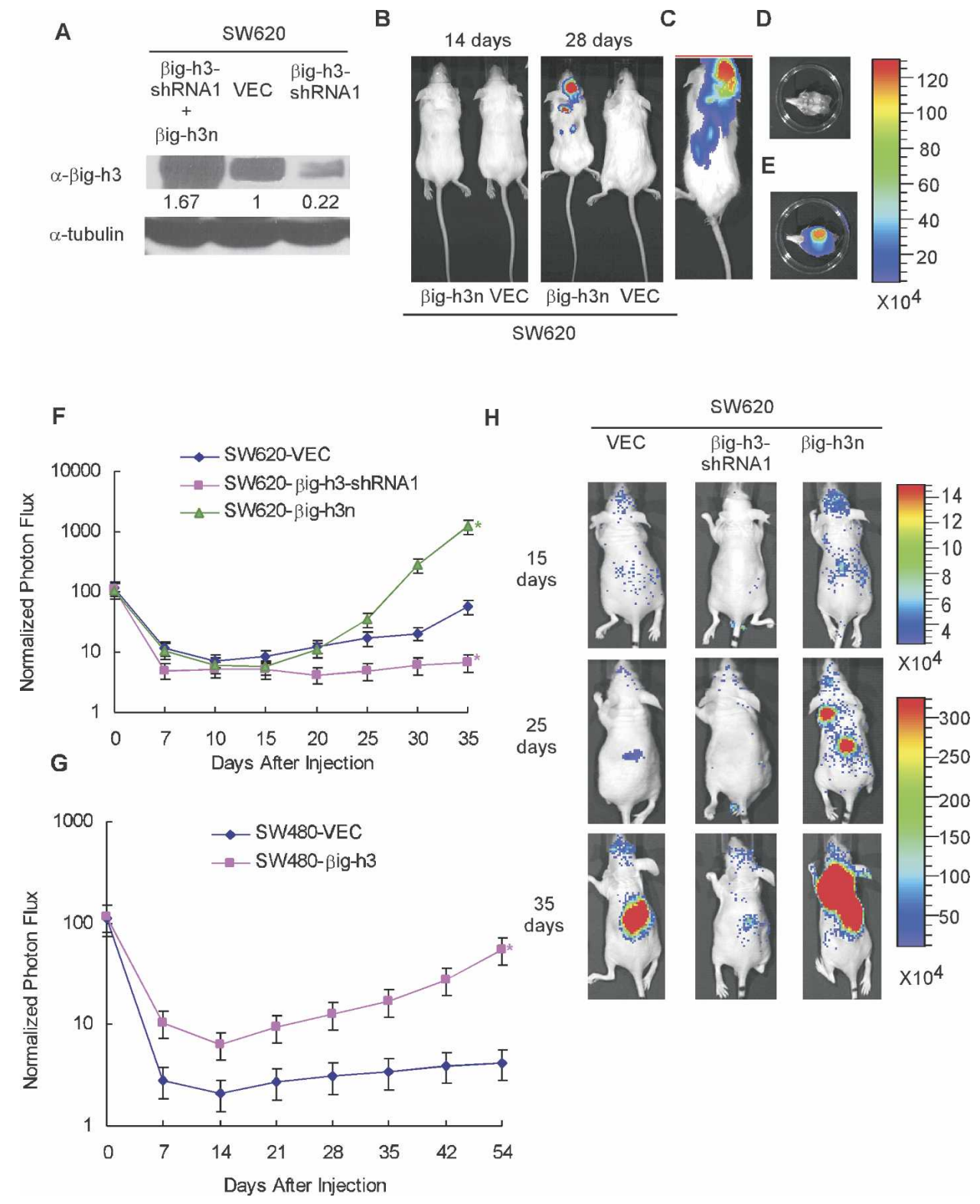

Figure 3. The metastatic properties of SW620 cells with different levels of $\beta$ ig-h3 expression. (A) The expression level of $\beta$ ig-h3 in

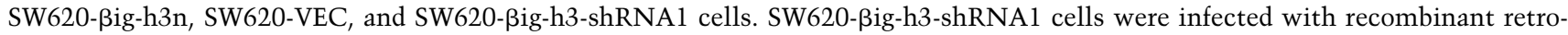
viruses containing shRNA-resistant $\beta$ ig-h3 full-length cDNA ( $\beta i g-h 3 n)$ tagged with the Flag-epitope (SW620- $\beta$ ig-h3n). An equal amount of concentrated supernatant from each cell type as indicated was examined for the presence of $\beta$ ig-h3 by Western blot using an anti- $\beta$ ig-h3 antibody. The whole-cell lysate from each sample of cells from which the supernatant was collected for the determination of $\beta$ ig-h3 expression was blotted with anti-tubulin antibody for loading control. $(B)$ Mice were injected intravenously with SW620- $\beta$ ig-h3n or SW620-VEC cells expressing a luciferase gene and subjected to in vivo imaging at indicated time points, with relative light unit counts indicated in color. $(C)$ In vivo bioluminescent imaging of a mouse 4 wk after being inoculated with SW620-ßig-h3n cells. $(D, E)$ At necropsy, the skull (without brain tissue) of the same mouse shown in $C$ was removed and imaged ex vivo for photographic $(D)$ and bioluminescence $(E)$ imaging. $(F, G)$ SW620- and SW480-derived cells as indicated were inoculated intracardially into 5-wk-old nude mice. SW620 or SW480 cells were labeled with luciferase, and $1 \times 10^{6}$ cells were injected into the left cardiac ventricle of five mice for each group. At the indicated days after inoculation, bioluminescence images were acquired. Tumor metastasis was measured by bioluminescence and quantified. Results are the mean \pm SD of five animals from each group. $\left({ }^{\star}\right)$ $P<0.05$. Two independent experiments were performed. $(H)$ Representative in vivo bioluminescent images of animals after intracar-

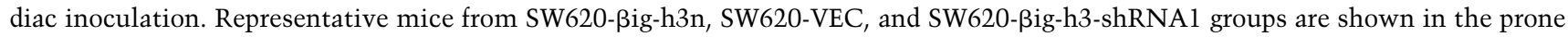
position, with relative light unit counts indicated in color.

vessel density was similar in xenograft tumors derived from $\beta$ ig-h3-overexpressing and control cells, which sug- gests that $\beta$ ig-h3 is not actively involved in the induction of angiogenesis (data not shown). Thus, although 
highly homologous to periostin, $\beta$ ig-h3 promotes tumor metastasis through a distinct mechanism.

As mentioned earlier, the average size of metastatic lung tumor nodules was not affected by the different levels of $\beta$ ig-h3 expressed by the constituent cancer cells (Supplemental Fig. S2; Supplemental Tables S5, S6), indicating that $\beta$ ig-h3 expression may not function to accelerate cell proliferation. Consistent with this notion, ectopic $\beta$ ig-h3 expression only slightly enhanced subcutaneous tumor growth of the SW480 tumors (Supplemental Fig. S5A), and the proliferation rate of the SW480-VEC and SW480- $\beta$ ig-h3 cells was comparable (Supplemental Fig. S5B).

One of the critical steps in metastasis that may contribute to these outcomes under the assaying conditions is the extravasation of cancer cells through the blood vessel wall to reach distal organs. To assess the potential function of $\beta$ ig-h3 in extravasation, we used an in vitro TEM assay to test the effect of $\beta$ ig-h3 expression on the TEM capability of colon cancer cells in order to mimic the in vivo behavior of cancer cells undergoing extravasation (Voura et al. 2001). As shown in Figure 4A, SW480 cells were allowed to migrate through a monolayer of human umbilical vein endothelial cells (HUVECs). The TEM process was three times more efficient with $\beta i g-h 3$ overexpression. Consistent with this result, shRNA knockdown of $\beta$ ig-h3 in SW620 cells similarly reduced the ability of those cells to migrate through the HUVEC layer in comparison with the vector control cells (Fig. 4B). Similar results were obtained by using primary human microvascular endothelial cells and immortalized human bone marrow-derived endothelial cells (data not shown), suggesting that the proextravasation function of $\beta i g-h 3$ is not limited to one type of endothelial cell. On the other hand, this effect of $\beta$ ig-h3 is endothelial cellspecific, because the tumor cells with different levels of Big-h3 showed no differences in their ability to migrate through either the fibroblast monolayer or matrigel (Supplemental Fig. S6). These findings provide a potential cellular mechanism (extravasation) for the observed in vivo phenotype of increased formation of metastatic colonies in various organs and tissues of the mice by the colon cancer cells through intravenous or intracardiac inoculation.

It has been established that the permeability of the blood vessel wall is in part controlled by VE-cadherindependent junctions between endothelial cells /Vestweber 2002). To intravasate and extravasate the blood vessel, cancer cells often need to acquire the ability to breach the endothelial cell barrier. This process likely occurs through the induction of changes in the organization and integrity of the VE-cadherin junctions, leading to disruption of the interendothelial cell contacts, which in turn allows tumor cells to successfully migrate through (Allport et al. 1997). To examine the capability of $\beta$ ig-h3 to induce changes at the interendothelial cell contacts, fluorescent dye-labeled colon cancer cells with different $\beta$ ig-h3 expression levels were laid on top of the endothelial monolayer, and cells were stained $4 \mathrm{~h}$ later with an anti-VE-cadherin antibody to assess the integrity of the intercellular junctions. The colocalization of fluorescence-labeled cancer cells and VE-cadherin junction disruption (indicated by VE-cadherin immunostaining) was examined using fluorescence microscopy, and the frequency of colocalization was quantified (Sandig et al. 1997). The presence of high-level ßig-h3 significantly increased the frequency of VE-cadherin junction disruption in the endothelial monolayer (Fig. 4C,D), which indicates that $\beta$ ig-h3 promotes TEM by facilitating VEcadherin reorganization and junction dissociation. To further examine the effect of $\beta$ ig-h3 on the integrity of intercellular junctions, we performed a vascular permeability assay (Lampugnani et al. 1992) by treating an intact endothelial monolayer with conditioned media from three types of SW620-derived cells that contain different levels of $\beta$ ig-h3. The permeability of the endothelial monolayer for FITC-coupled dextran was determined at several time points by measuring the fluorescence intensity of the media in the lower compartment. As shown in Figure 4E, the permeability of the endothelial monolayer is proportionally associated with the level of $\beta$ ig-h 3 present in the media. These results suggest that $\beta i g-h 3$ enhances extravasation by inducing VE-cadherin junction dissociation, leading to the increase of vascular permeability of the endothelial monolayer.

To determine whether the proextravasation activity of ßig-h3 observed under the in vitro assaying conditions is an accurate reflection of its capability in vivo, we monitored the impact of $\beta$ ig-h3 on the ability of colon cancer cells to accumulate in the lungs of mice $24 \mathrm{~h}$ after their inoculation via the tail vein as a measure of the extravasation activity following an established protocol (Gupta et al. 2007). As shown in Figure 4, F and G, reduction in Big-h3 expression significantly suppressed the number of cancer cells accumulated in the lung, a strong indication that $\beta$ ig-h3 plays a positive role in the extravasation process during tumor metastasis.

\section{ßig-h3-mediated VE-cadherin junction dissociation requires integrin $\alpha_{v} \beta_{5}$}

As a secreted protein containing multiple integrin-interacting domains, $\beta$ ig-h3 has been shown to interact with various types of integrins, including $\alpha_{v} \beta_{3}, \alpha_{v} \beta_{5}, \alpha_{3} \beta_{1}$, and $\alpha_{6} \beta_{4}$ (Bae et al. 2002; Kim et al. 2003; Nam et al. 2003; Lee et al. 2006). Among them, $\alpha_{v} \beta_{3}$ and $\alpha_{v} \beta_{5}$ have been demonstrated previously to be associated with the extravasation process (Weerasinghe et al. 1998; Su et al. 2006). As an initial attempt to determine if integrin $\alpha_{v} \beta_{3}$ or $\alpha_{\mathrm{v}} \beta_{5}$ is involved in mediating the activity of $\beta$ ig-h3 in promoting TEM, we pretransfected endothelial cells with an siRNA specifically against integrin $\alpha_{\mathrm{v}}$ to reduce its expression (Supplemental Fig. S7). The TEM activities of the SW480 cancer cells with or without Big-h3 expression through the modified endothelial cell monolayer were assayed $48 \mathrm{~h}$ after siRNA transfection. As shown in Figure 5A, knocking down integrin $\alpha_{\mathrm{v}}$ in the endothelial cells reduced the advantage of SW480- $\beta i g-h 3$ cells in their gained TEM activity over the control cells, 
Figure 4. $\beta$ ig-h3 promotes cancer cell TEM activity in vitro. $(A, B)$ The presence of $\beta$ ig-h3 is associated with increased activity in TEM by colon cancer cells. HUVECs $\left(5 \times 10^{4}\right)$ were plated on the matrigel-coated porous insert in the chambers and maintained overnight in culture to allow the endothelial cells to form a monolayer. Colon cancer cells $\left(1 \times 10^{5}\right)$ labeled with 5-(and-6)-carboxyfluorescein diacetate, succinimidyl ester (CFSE) were then seeded on top of the HUVEC monolayer. After coculturing for $4 \mathrm{~h}$, the cancer cells attached to the bottom of the membrane were fixed for examination under epifluorescence microscope. Each experiment used quadruplicate wells, and within each well counting was done in five randomly selected microscopic high-power fields $(200 \times)$. Results are the mean \pm SD of quadruplicate wells. Four independent experiments were performed. $\left({ }^{\star}\right) P<0.01$ $(n=4) .(C)$ Monolayers of HUVECs were formed on the matrigel-coated coverslips as described in $A$ and $B$. CFSE-labeled colon cancer cells were laid on top of the endothelial monolayer, and samples were taken at $4 \mathrm{~h}$ to stain with anti-VE-cadherin antibody (BV9). The colocalization of fluorescent-labeled cancer cells with or without $\beta$ ig-h3 expression and VE-cadherin junction disruption in the endothelial monolayer was examined by fluorescence microscopy. Representative images of the colocalization of tumor cells and VE-cadherin junctions that exhibit either dissociated or intact VE-cadherin junctions are shown. (D) Quantification of frequency for the colocalization of SW480 cancer cells with or without $\beta$ ig-h3 expression and VEcadherin junction dissociation. Each experiment used triplicate coverslips, and within each coverslip 300 CFSE-positive cancer cells were counted. Results are the mean $\pm \mathrm{SD}$ of three independent experi-

A
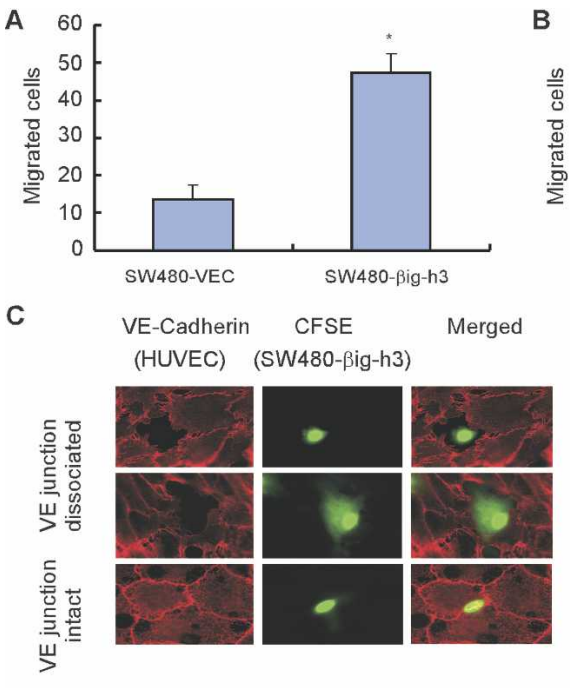

E

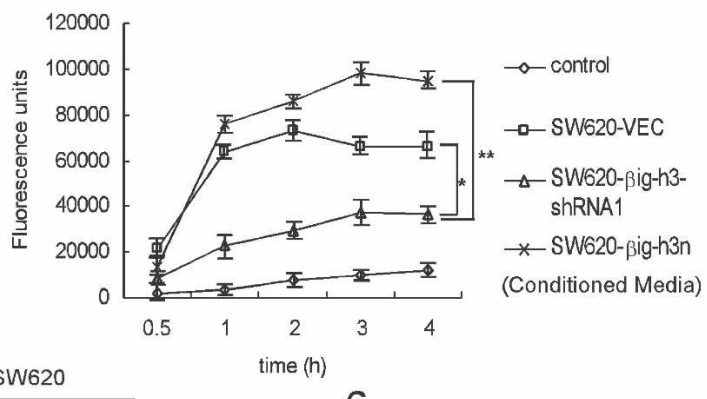

$\mathbf{F}$

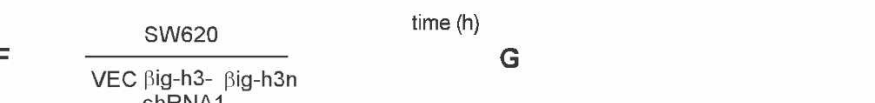

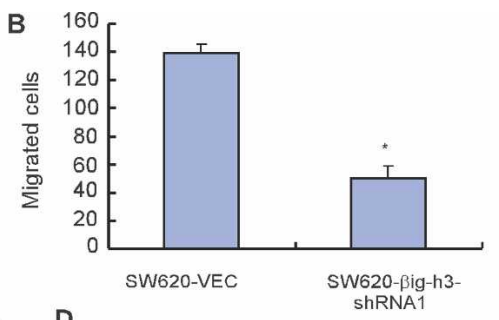
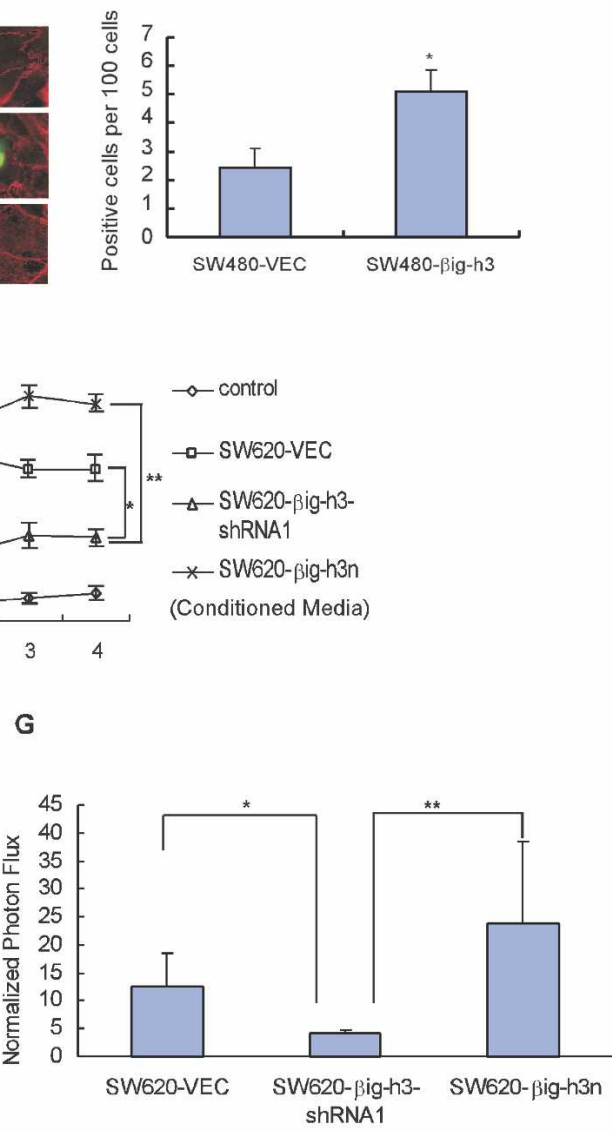

ments. $\left({ }^{\star}\right) P<0.01(n=9)$. (E) Big-h3 stimulates permeability in the HUVEC monolayer. A confluent layer of HUVEC cells on Transwell filter inserts was used. Monolayer permeability after addition of indicated conditioned media from SW620-derived cells was measured using FITC-dextran $\left(\mathrm{Mr} 40 \times 10^{3}\right)$ as described in the Materials and Methods. Results are the mean \pm SD of triplicate wells. Three independent experiments were performed. $\left(^{\star}\right) P<0.02 ;\left(^{\star \star}\right) P<0.01$. $(F)$ Representative in vivo bioluminescent images of

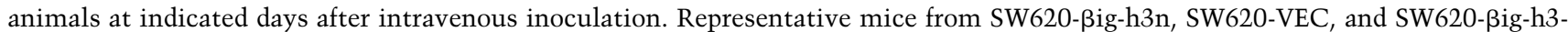
shRNAl groups are shown in the prone position, with relative light unit counts indicated in color. (G) SW620-derived cells were injected intravenously, and accumulation of cancer cells in the lung as indication of extravasation activity was measured via bioluminescence on day 1 . Results are the mean \pm SD of five animals from each group. $\left(^{\star}\right) P<0.05 ;\left(^{\star \star}\right) P<0.01$. Two independent experiments were performed.

but had a minimal effect on the SW480-VEC control cells. Consistent with these results, reduction of integrin $\alpha_{\mathrm{v}}$ expression in the endothelial cells also significantly blocked the TEM activity of SW620-VEC and SW620$\beta$ ig-h3n cells (Fig. 5B), suggesting that integrin $\alpha_{\mathrm{v}}$ is involved in $\beta$ ig-h3-mediated enhancement in TEM activity. The specific involvement of integrin $\alpha_{\mathrm{v}} \beta_{3}$ or $\alpha_{\mathrm{v}} \beta_{5}$ in this process was subsequently determined by pretreating the endothelial cell monolayer with specific blocking an- tibodies against integrin $\alpha_{\mathrm{v}} \beta_{3}$ or $\alpha_{\mathrm{v}} \beta_{5}$. As shown in Figure $5 \mathrm{C}$, only the antibody against $\alpha_{\mathrm{v}} \beta_{5}$ abolished the gained TEM activity of the SW480- $\beta$ ig-h3 cells over the control cells. This antibody against integrin $\alpha_{\mathrm{v}} \beta_{5}$ also eliminated the TEM advantage of SW620-VEC and SW620-Big-h3n cells over the shRNA knockdown cells (Fig. 5D). Collectively, these results indicate that integrin $\alpha_{\mathrm{v}} \beta_{5}$ is most likely the mediator of $\beta$ ig-h 3 activity in promoting TEM. 
A

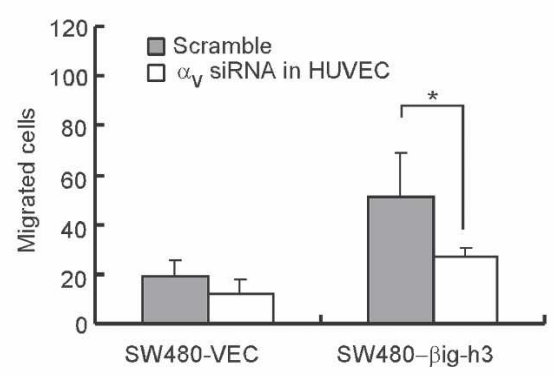

C

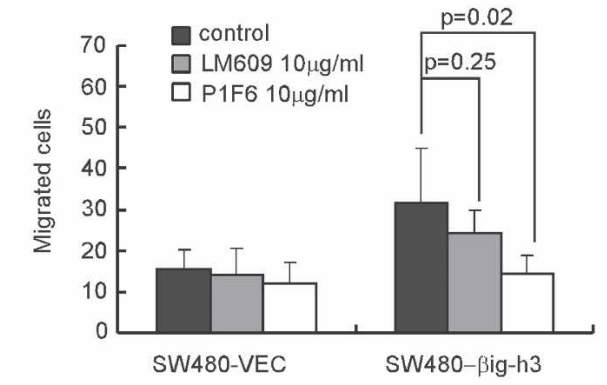

$E$

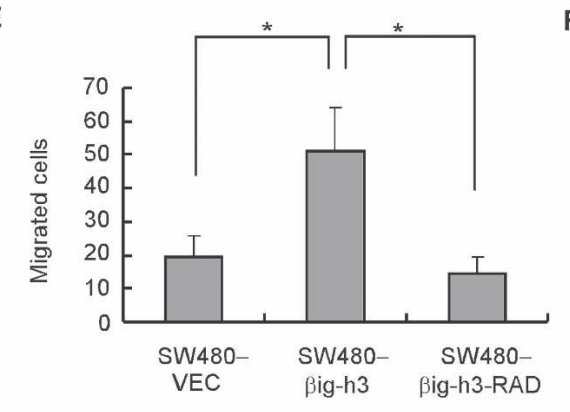

B

D
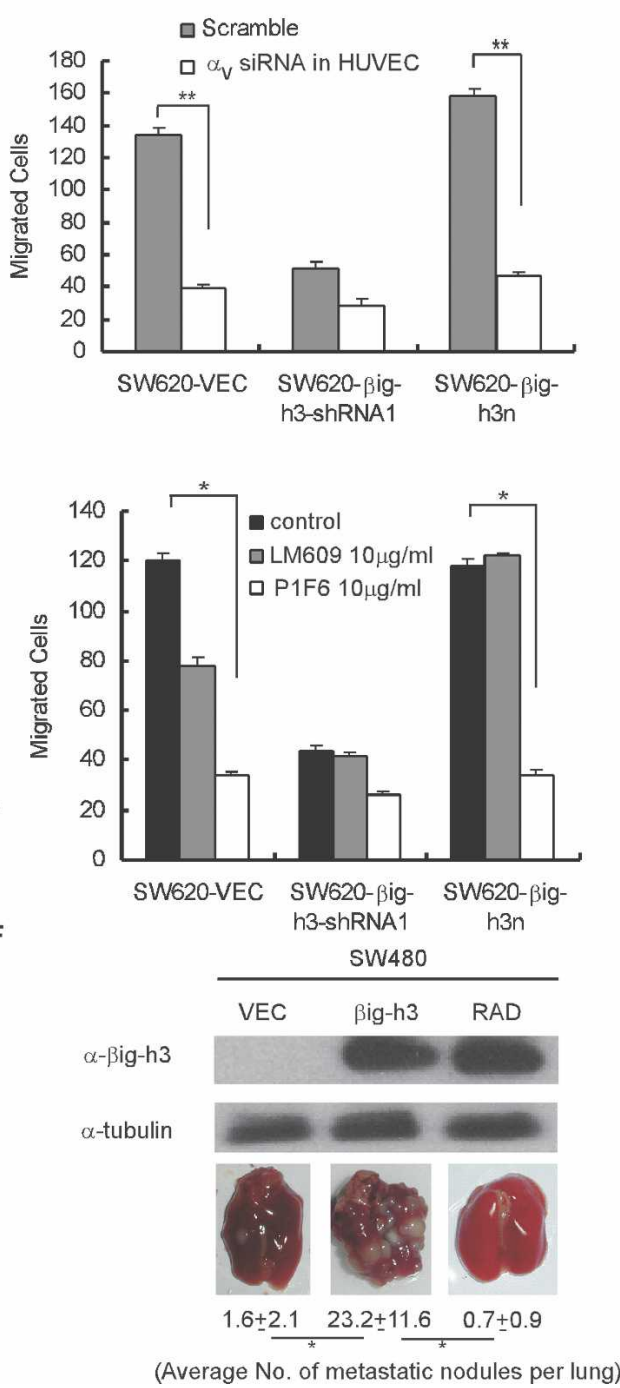

Figure 5. $\beta$ ig-h3-induced TEM is mediated through the $\alpha_{\mathrm{v}} \beta_{5}$ integrin. $(A, B)$ Knockdown of integrin $\alpha_{\mathrm{v}}$ on the surface of HUVECs results in the reduction of $\beta$ ig-h3-induced TEM activity. HUVECs were transfected with control or integrin $\alpha_{\mathrm{v}}$ siRNA $24 \mathrm{~h}$ before being plated on the matrigel-coated porous insert. A TEM assay was performed $48 \mathrm{~h}$ after siRNA transfection as described in Figure 4 . Results are the mean $\pm \mathrm{SD}$ of quadruplicate wells. Four independent experiments were performed. $\left.\left(^{\star}\right) P<0.02 ;{ }^{\star \star}\right) P<0.01$. $(C, D)$ The presence of blocking antibody against integrin $\alpha_{v} \beta_{5}$ but not $\alpha_{v} \beta_{3}$ eliminates $\beta$ ig-h3-induced increase in TEM activity. HUVEC monolayer was pretreated with the indicated concentration of blocking antibody LM609 against integrin $\alpha_{\mathrm{v}} \beta_{3}$ or P1F6 against integrin $\alpha_{\mathrm{v}} \beta_{5}$ for 30 min before the CFSE-labeled cancer cells were added and a TEM assay was performed as described earlier. Results are the mean \pm SD of quadruplicate wells. Four independent experiments were performed. $\left.{ }^{\star}\right) P<0.01$. (E) RGD $\rightarrow$ RAD mutation in $\beta$ ig-h3 abolishes Big-h3-induced increase in TEM activity. TEM assay was performed as described previously with indicated cell lines. Results are the mean \pm SD of quadruplicate wells. Four independent experiments were performed; $\left({ }^{\star}\right) P<0.01$. $(F)$ SW480 cells (parental) were infected with recombinant retroviruses containing either vector control (VEC), $\beta i g-h 3$ full-length cDNA ( $\beta i g-h 3$ ), or $\beta i g-h 3-R A D$ cDNA (RAD). An equal amount of concentrated supernatant from each cell type as indicated was examined for the presence of $\beta i g$-h3 by Western

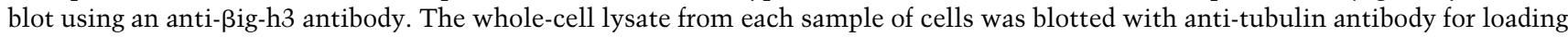
control. (Bottom panel) Representative results showing the formation of metastases in the lung of mice injected with SW480-derived cells. We injected $4 \times 10^{6}$ SW480-VEC, SW480- $\beta$ ig-h3, or SW480- $\beta$ ig-h3-RAD cells through the tail vein into 5-wk-old SCID-Beige mice. Mice were sacrificed and examined for the growth of metastatic tumors $12 \mathrm{wk}$ after injection. The average numbers of metastatic nodules in individual mouse are shown. The counting was performed under a dissection scope. $\left(^{\star}\right) P<0.01(n=10)$.

The RGD motif of $\beta$ ig-h3 protein is required for Big-h3-induced TEM

Big-h3 possesses a RGD sequence at its C terminus, which is a known ligand-binding motif for integrins
(Delannet et al. 1994). To probe whether the proextravasation activity of $\beta$ ig-h3 is mediated via the RGD motif, a mutant form of $\beta$ ig-h3 was generated by changing RGD to RAD with a glycine-to-alanine substitution. This mutant $\beta$ ig-h3 was introduced into SW480 cells via retrovi- 
Ma et al.

ral infection to an expression level comparable with that of the wild-type protein (Fig. 5F). As shown in Figure 5E, the RAD mutant of $\beta$ ig-h3 failed to facilitate the TEM of SW480 cells in comparison with wild-type $\beta$ ig-h3. More strikingly, $12 \mathrm{wk}$ after tail vein injection, the SW480-Bigh3-RAD cells barely formed any lung metastases (Fig. $5 F)$. Taken together, these results suggest that the RGD motif in $\beta$ ig-h3 is essential for activating integrin $\alpha_{v} \beta_{5}$ to promote TEM and lung metastasis of the colon cancer cells.

To further examine the role of the RGD motif in the $\beta$ ig-h3-stimulated TEM process, we synthesized a blocking peptide corresponding to amino acids 636-655 of $\beta$ igh3 containing the RGD motif, and a mutant peptide with the same sequence except for the glycine-to-alanine substitution (Fig. 6A). Vascular permeability assays were performed following pretreatment of the intact endothe- lial monolayer with the two peptides, respectively. As seen earlier in Figure 4E, Big-h3-conditioned media increased the permeability of the HUVEC monolayer, and this increase was almost completely abolished by preincubation of the HUVEC cells with the blocking peptide (Fig. 6B,C). Note that the RAD peptide had no effect on Big-h3 activity in parallel assays (Fig. 6B,C). These results again suggest that the RGD motif is required for the $\beta$ ig-h3-induced increase in vascular permeability of the endothelial monolayer.

\section{Big-h3 stimulates the activation of Src kinase and tyrosine phosphorylation of $\beta$-catenin in endothelial cells}

Previous studies have shown that the tyrosine kinase Src serves as an effector downstream from the integrins. Src
Figure 6. $\beta$ ig-h3-induced TEM requires the RGD motif and Src kinase activation. (A) Sequences of the RGD and RAD peptides. The numbers represent the positions of the animo acids on the $\beta$ ig-h3 protein. $(B, C)$ The RGD peptide blocks the $\beta$ ig-h3-induced permeability in the HUVEC monolayer. Confluent layers of HUVEC cells on Transwell filter inserts were pretreated with each peptide for $1 \mathrm{~h}$ at the indicated concentration. Monolayer permeability after addition of conditioned media from SW480- and SW620-derived cells as indicated was measured using FITC-dextran $\left(\mathrm{Mr} 40 \times 10^{3}\right)$ as described in the Materials and Methods. Results are the mean \pm SD of triplicate wells. Three independent experiments were performed. $\left(^{*}\right) P<0.05$. (D) Big-h3-induced TEM activity is associated with the activation of Src kinase in endothelial cells. $\beta i g-h 3$-producing, $\beta i g$ h3-RAD-producing, or control SW480 cells were grown in normal media until $80 \%$ confluency and then cultured in serum-free media for $24 \mathrm{~h}$. Supernatant was collected as conditioned media. HUVEC cells were grown in normal media until $75 \%$ confluency and then cultured in serum-free media for 16 h. Conditioned media from $\beta$ ig-h3-producing, $\beta$ igh3-RAD-producing, or control SW480 cells were applied to the HUVEC cells, respectively. Cell lysates were harvested at indicated time points and analyzed by immunoblotting with the anti-pY416-Src and anti-Src antibodies. (E) Src kinase activation is associated with tyrosine phosphorylation of $\beta$-catenin in the endothelial cells. The same type of experiment was performed as described in $D$. Cell lysates harvested at indicated time points were incubated with anti- $\beta$-catenin antibody. Immunoprecipitates were blotted with anti-phospho-tyrosine antibody. $(F, G)$ Src inhibitor PP1 blocks the Big-h3induced permeability in the HUVEC monolayer. Confluent layers of HUVEC cells on Transwell filter inserts were pretreated with $170 \mathrm{nM}$ PP1 Src inhibitor for $1 \mathrm{~h}$. Monolayer permeability after addition of conditioned media from the indicated cell types was measured using FITC-dextran $\left(\mathrm{Mr} 40 \times 10^{3}\right)$ as described in the Materials and Methods. Results are the mean \pm SD of triplicate wells. Three independent experiments were performed. $\left(^{\star}\right) P<0.01$.

\section{A RGD peptide: 636 ANRPQERGDELADSALEIFK 655} RAD peptide: 636 ANRPQERADELADSALEIFK 655
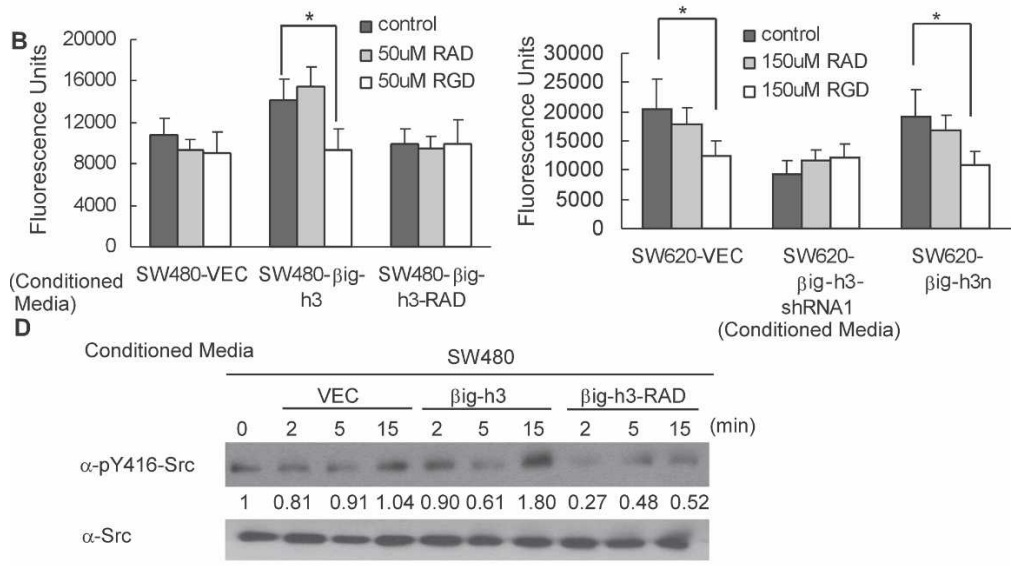

E

Conditioned Media
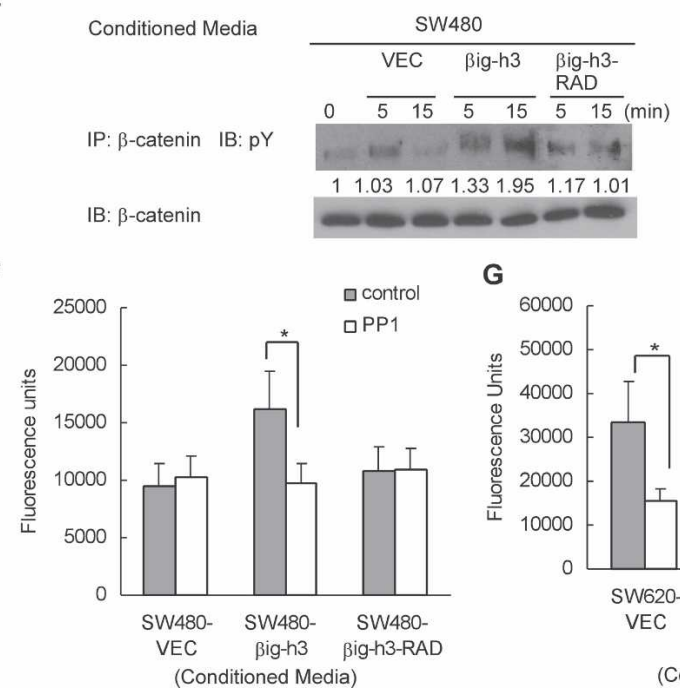

G

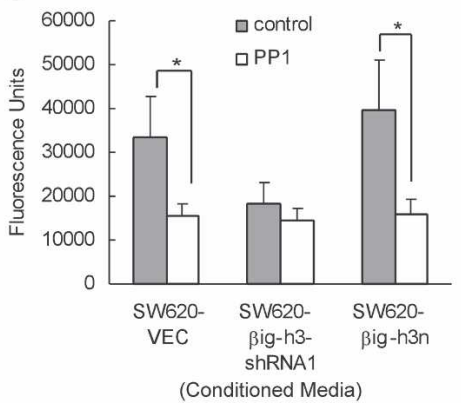


activation results in VE-cadherin and $\beta$-catenin phosphorylation on specific tyrosine residues, leading to the dissociation of the VE-cadherin/ $\beta$-catenin complex and breakdown of the endothelial barrier (Weis et al. 2004). To test if the Src pathway in the endothelial cells mediates $\beta$ ig-h3-induced TEM of cancer cells, we examined Tyr416 phosphorylation of Src, which is indicative of the activated state of the kinase (Hunter 1987). As shown in Figure 6D, a higher level of active Src was detected in the endothelial cells incubated with conditioned media derived from SW480- $\beta$ ig-h3 cells than in those incubated with media from the SW480-VEC and SW480- $\beta$ ig-h3RAD cells. Moreover, the $\beta$ ig-h3-mediated activation of Src kinase is associated with an enhancement in tyrosine phosphorylation of $\beta$-catenin in the endothelial cells (Fig. 6E). On the other hand, blocking Src activity by the kinase inhibitor 4-amino-5-(4-methylphenyl)-7-(t-butyl) pyrazolo [3,4-d]-pyrimidine (PP1) specifically abrogated $\beta$ ig-h3-induced, but not basal-level, TEM activity of the cancer cells (Fig. 6F,G). Taken together, these data strongly suggest that $\beta$ ig-h3-induced TEM is dependent on the $\alpha_{\mathrm{v}} \beta_{5}$ integrin-Src signaling pathway, the activation of which requires the $\beta$ ig-h3 RGD motif.

\section{Discussion}

Several recent reports have highlighted extravasation as a critical step of tumor metastasis that is regulated by various types of secreted or cell surface proteins (Gupta et al. 2007; Karnoub et al. 2007). In one study, four of such proteins expressed by human breast cancer cells were shown to collectively facilitate the breaching of lung capillaries by circulating tumor cells to seed pulmonary metastasis (Gupta et al. 2007). In another study, breast cancer cells were demonstrated to stimulate de novo secretion of the chemokine CCL5 from mesenchymal stem cells, which in turn acts in a paracrine fashion on the cancer cells to enhance the extravasation process (Karnoub et al. 2007). The data presented here demonstrate that the ECM protein $\beta$ ig-h3 promotes colon cancer metastasis primarily at the extravasation step. A lowmetastatic colon cancer cell line, SW480, engineered to overexpress $\beta$ ig-h3 displayed a phenotype of greatly enhanced tumor metastasis, whereas down-regulation of $\beta$ ig-h3 in the aggressive isogenic cell line resulted in an almost complete elimination of the metastatic potential when tested in our animal model systems. $\beta$ ig-h3 directly or indirectly interacts with integrin $\alpha_{\mathrm{v}} \beta_{5}$ on the surface of endothelial cells, and this interaction consequently induces Src activation, which leads to tyrosine phosphorylation of $\beta$-catenin, dissociation of VE-cadherin junction, and eventual breakdown of the endothelial barrier. The integrin $\alpha_{\mathrm{v}} \beta_{5}$ and the Src signal pathway have both been implicated in the extravasation process (Weis et al. 2004; Su et al. 2006). The establishment of an association between $\beta$ ig-h3 and the integrin $\alpha_{\mathrm{v}} \beta_{5}-\mathrm{Src}$ signaling pathway thus provides a molecular mechanism for the novel proextravasation role of $\beta$ ig-h3 in the context of colon cancer metastasis.

In addition to colon cancer, $\beta$ ig-h3 up-regulation is also observed in cancers of other organs such as pancreas (Schneider et al. 2002). Although the potential function of $\beta$ ig-h3 in pancreatic cancers is not known, the aberrant expression of $\beta i g-h 3$ may contribute to the pathologic phenotype of the disease in a similar way as in colon cancer. Intriguingly, besides the changes of ßig-h3 expression in epithelial cancer cells, aberrant expression of $\beta$ ig-h3 is also found in cancer-associated fibroblasts/ myofibroblasts, including colon and breast cancers (Buckhaults et al. 2001; Allinen et al. 2004; data not shown). The tumor microenvironment may extensively influence gene expressions in the cancer-associated fibroblasts, which in turn secrete growth factors and/or ECM proteins (such as $\beta$ ig-h3) that react on the tumor microenvironment (Bhowmick et al. 2004; Mueller and Fusenig 2004; Grum-Schwensen et al. 2005; Orimo et al. 2005; Orimo and Weinberg 2006). It is important to note that, unlike a bone fide growth factor or oncoprotein that stimulates cell proliferation, ßig-h3 showed no mitogenic activity on cancer cells under in vitro assaying conditions (Supplemental Fig. S5B; data not shown). Rather, this ECM protein acts in vivo to promote metastasis by altering the tumor microenvironment.

As the nomenclature implies, $\beta$ ig-h3 was originally identified as a TGF- $\beta$-inducible gene (Skonier et al. 1992). Since TGF- $\beta$ has been implicated in promoting tumor metastasis (Kang et al. 2005; Bierie and Moses 2006; Gomis et al. 2006), it is possible that $\beta$ ig-h3 acts as an effector in mediating the prometastatic activity of TGF- $\beta$ in certain cancers. A recent study on breast tumor heterogeneity (Shipitsin et al. 2007) showed that cells in breast tumors can be categorized according to $\mathrm{CD} 44^{+}$and $\mathrm{CD} 24^{+}$expression. Tumors consisting of cells with high $\mathrm{CD} 44^{+}: \mathrm{CD} 24^{+}$ratios tend to develop distant metastases, particularly to the bone (Shipitsin et al. 2007). Gene expression profile analyses of these cells show that TGF- $\beta$ signaling and $\beta$ ig-h3 expression are specifically up-regulated in the $\mathrm{CD} 44^{+}$cells, indicating a potential role of TGF- $\beta$ signaling in tumor metastasis and a potential link between TGF- $\beta$ action and $\beta$ ig-h3 expression in CD44 ${ }^{+}$ breast cancer cells.

In previous studies, we identified periostin, a structural homolog of $\beta$ ig-h3, as a positive regulator of colon cancer progression. Periostin potently promotes colon cancer metastasis by augmenting cell survival via the integrin-Akt/PKB pathway (Bao et al. 2004). Interestingly, although periostin and $\beta$ ig-h3 share significant sequence and structural homology (Supplemental Fig. S1), these two proteins are involved in different processes during tumor development, which is likely due to the differences in their C-terminal structure. Big-h3 has a short $\mathrm{C}$ terminus that contains a RGD motif, while periostin possesses a relatively long hydrophilic $\mathrm{C}$ terminus without the RGD sequence. The differences in their $\mathrm{C}$ termini may contribute to their differential binding specificities with different types of integrins, which in turn result in diverse impacts on tumor progression. It is intriguing that the $\beta$ ig-h3-RAD mutant apparently exerted a dominant-negative effect on the formation of lung metastasis by the SW480 cells (Fig. 5F), suggesting 
that other molecules that possess similar activities as Big-h3 may also be involved in the metastatic process. In addition, we found that a small $\beta$ ig-h3-derived peptide effectively blocked the TEM of cancer cells, indicating an intriguing possibility that $\beta$ ig-h3 can be a potential therapeutic target for treating metastatic colon cancer.

\section{Materials and methods}

\section{Immunohistochemical staining}

Paraffin-embedded lung tissue sections from mice inoculated with SW480- $\beta$ ig-h3 or SW480-VEC cancer cells or TMA slides were processed for antigen retrieval by heating in $10 \mathrm{mM}$ sodium citrate $(\mathrm{pH} 6.0)$ for $20 \mathrm{~min}$ at $95^{\circ} \mathrm{C}$. Then, sections were immunostained with a polyclonal antibody against the recombinant human $\beta$ ig-h3 protein (Proteintech Group, Inc., catalog no. 10188-1-AP). The immunostaining was performed with an ABC staining system (Vector Laboratories) using the avidin-biotinylated-peroxidase detection method.

\section{Criteria for TMA evaluation}

Immunoreactivity of $\beta$ ig-h3 was semiquantitatively examined by a pathologist (M. Datto) as described previously (Reed et al. 2002). For each tumor, represented by TMA staining, we determined the tumor epithelial cells' proportion score and intensity score. Peritumoral inflammatory and stromal cells were not included in the evaluation. The proportion score included the fraction of positively stained tumor cells and was as follows: 0 $(0 \%), 1(1 \%-33 \%)$, $2(34 \%-66 \%) ; 3(67 \%-100 \%)$. The positive reaction is scored into four grades, according to the intensity of the staining as follows: $0 ; 1+; 2+; 3+$. The product of the intensity by percentage scores is used as the final score. For the statistical analysis, a score of 0 was considered negative, a score of 1-3 was considered weak, a score of 4-6 was considered moderate, and a score of 7-9 was considered strong.

\section{Statistical analysis}

The immunohistochemical staining results were analyzed by using the ANOVA F test. A pairwise comparison was done between different tumor grades.

\section{Plasmids}

A cDNA sequence encoding Flag epitope-tagged $\beta$ ig-h3 was cloned into the SnaBI/SalI sites of pBabe-puro (Morgenstern and Land 1990) to generate pBabe- $\beta$ ig-h3-Flag-puro. Retroviral vectors that encode shRNAs against the $\beta$ ig-h 3 transcript were generated by cloning oligonucleotide sequences into the pSUPERretro-puro (Brummelkamp et al. 2002) vector. The coding sequences of the $\beta$ ig-h3 targeting shRNAs were CCAGCTGGC CTCTAAGTAT ( $\beta$ ig-h3-shRNA1) and CACGATGCTTGAAG GTAAC (ßig-h3-shRNA2). shRNA-resistant mutations were generated by site-directed mutagenesis in the coding sequence of Ala445 (GCC $\rightarrow$ GCA) and Ser446 (TCT $\rightarrow$ TCG) to create an shRNA-resistant version of the $\beta$ ig-h3 expression plasmid pBabe- $\beta$ ig-h3n-Flag-neo. pMCVS-luciferase was a generous gift from Dr. P. Casey of Duke University.

\section{Cell culture and transfection}

SW480/SW620 and their various derivatives of cell populations, as well as $293 \mathrm{~T}$ cells, were cultured in DMEM growth medium
(Invitrogen Corp.) supplemented with 10\% FBS and antibiotics. The HUVECs and human microvascular endothelial cells (HMVECs; Clonetics) were maintained in endothelial growth medium (EGM-2-MV; Clonetics) supplemented with 5\% FBS (Clonetics). The human bone marrow-derived endothelial cells (HBMEC-28 and HBMEC-60) were maintained in M199 (Invitrogen Corp.) supplemented with 10\% FBS and 10\% heat-inactive human serum (Sigma) as described previously (Schweitzer et al. 1995). Retroviruses expressing $\beta$ ig-h3 shRNA, $\beta i g-h 3$-Flagpuro, $\beta$ ig-h3n-Flag-neo, or luciferase were produced from the 293T packaging cell line. 293T cell transfections were performed using FuGene 6 reagent (Roche) according to the manufacturer's instructions. Viruses were harvested 48 and $72 \mathrm{~h}$ after transfection, filtered, and used to infect SW480 or SW620 cell cultures in the presence of $5 \mu \mathrm{g} / \mathrm{mL}$ polybrene. Infected cells were selected for puromycin or G418 resistance.

Subcutaneous injection Cancer cells were harvested from subconfluent cell culture plates, washed with PBS, and resuspended at a concentration of $2.5 \times 10^{7}$ cells per milliliter of DMEM with $10 \%$ FBS. Of the suspending cells, $0.2 \mathrm{~mL}$ was injected into 5-wk-old SCID-Beige mice (Charles River Laboratories) with five mice for each group. Twelve weeks after injection, mice were sacrificed and examined for the growth of subcutaneous tumors. Four independent experiments were performed.

Intravenous injection Cancer cells were harvested at a concentration of $2 \times 10^{7}$ cells per milliliter of DMEM with $10 \%$ FBS. Of the suspending cells, $0.2 \mathrm{~mL}$ was injected through the tail vein into 5 -wk-old SCID-Beige mice using 30-gauge needles with five mice for each group. Mice were sacrificed and examined for the growth of metastatic tumors at various time points. Mice injected with SW480-Big-h3 or SW480-VEC cells were sacrificed $12 \mathrm{wk}$ after injection. Mice injected with SW620-VEC or SW620-ßig-h3-shRNA cells were sacrificed $7 \mathrm{wk}$ after injection. Mice injected with SW620-Big-h3n cells were sacrificed $4 \mathrm{wk}$ after injection. Four independent experiments were performed for each pair of cancer cells.

Intracardiac injections Cells were harvested at a concentration of $1 \times 10^{7}$ cells per milliliter of PBS. We injected $1 \times 10^{6}$ into the left cardiac ventricle of 5 -wk-old, female BALB/c-nu/nu nude mice (National Cancer Institute) using 27-gauge needles (Yin et al. 1999). Mice were anesthetized with $2.5 \%$ avertin (20 $\mathrm{mL}$ per $1 \mathrm{~kg}$ of body weight) before injection. A successful injection was indicated by the pumping of arterial blood into the syringe and confirmed by immediate bioluminescence imaging. All animals were maintained in a specific pathogen-free facility, and all studies were conducted under protocols approved by the Duke University Institutional Animal Care and Use Committee.

\section{Bioluminescence imaging}

Animals were injected with $10 \mathrm{mg} / \mathrm{kg}$ D-luciferin (Xenogen) in PBS intraperitoneally and anesthetized by isofluorane using the XGI-8 gas anesthesia system (Xenogen). Bioluminescence images were acquired by using the IVIS Imaging System (Xenogen) 10-15 min after injection. The acquisition time was $60 \mathrm{sec}$.

Western blot analysis, immunoprecipitation, and antibodies

For the detection of secreted $\beta$ ig-h3 protein, ßig-h3-producing or control cells were grown in normal media until $80 \%$ confluency and then cultured in serum-free media for $24 \mathrm{~h}$. The serum-free 
conditioned media were collected and analyzed by immunoblot with a specific anti- $\beta$ ig-h3 polyclonal antibody (Proteintech Group, Inc.), anti-Flag antibody (Sigma). As a loading control, whole-cell lysates were blotted with anti- $\gamma$-tubulin antibody (Sigma). For the detection of Src and other proteins, cell lysates were analyzed by immunoblotting with the anti-SRC (src-2; Santa Cruz Biotechnology, Inc.) and anti-pY416-SRC (Cell Signaling Technology, Inc.) rabbit polyclonal antibodies. To examine the tyrosine phosphorylation of $\beta$-catenin, HUVEC cells stimulated with conditioned media were harvested with RIPA lysis buffer (50 mM Tris- $\mathrm{HCl}$ at $\mathrm{pH} 7.4,150 \mathrm{mM} \mathrm{NaCl}, 1 \%$ Triton X-100, $1 \%$ sodium deoxycholate, $0.1 \%$ SDS) supplemented with protease inhibitors $(20 \mu \mathrm{g} / \mathrm{mL}$ leupeptin, $10 \mu \mathrm{g} / \mathrm{mL}$ pepstatin A, $10 \mu \mathrm{g} / \mathrm{mL}$ aprotonin, $1 \mathrm{mM}$ PMSF) and phosphatase inhibitors $(10 \mathrm{mM}$ sodium orthovanadate, $10 \mathrm{mM}$ sodium fluoride). The cleared lysates were immunoprecipitated with anti$\beta$-catenin antibody (E5; Santa Cruz Biotechnology, Inc.) and protein A/G-Sepharose. The immunoprecipitates were washed three times with lysis buffer, solubilized with SDS-PAGE sample buffer, electrophoresed, and analyzed by immunoblotting with anti-phospho-tyrosine antibody (4G10; Millipore). Anti- $\alpha_{\mathrm{v}} \beta_{3} \mathrm{mAb}$ (LM609; Chemicon, Inc.) and anti- $\alpha_{\mathrm{v}} \beta_{5} \mathrm{mAb}$ (P1F6; Chemicon) were used at $10 \mu \mathrm{g} / \mathrm{mL}$ for the functional blocking experiments. Quantification of results was aided by the ImageJ software (W.S. Rasband, U.S. National Institutes of Health; http://rsb.info.nih.gov/ij, 1997-2006).

\section{TEM assay}

HUVECs $\left(5 \times 10^{4}\right)$ were plated on the matrigel-coated porous insert in the chambers and maintained overnight in conditioned media to allow the endothelial cells to form a monolayer as described previously (Tremblay et al. 2006). Colon cancer cells $\left(1 \times 10^{5}\right)$ in suspension were labeled for $10 \mathrm{~min}$ with 5-(and-6)carboxyfluorescein diacetate, succinimidyl ester (CFSE; Molecular Probes) at $37^{\circ} \mathrm{C}$ and washed three times with PBS containing 5\% FBS. Cancer cells were then seeded on top of the HUVEC monolayer. After coculturing for $4 \mathrm{~h}$, the cancer cells attached to the bottom of the membrane were fixed for examination by epifluorescence microscopy. Each experiment used quadruplicate wells, and within each well counting was done in five randomly selected microscopic high-power fields (200x). Four independent experiments were performed. The same assay was repeated using HMVECs or HBMECs plated in monolayers in replacement of HUVECs.

\section{SiRNA transfection}

HUVECs or HMVECs were grown to $75 \%$ confluency in sixwell culture plates. Scramble or Integrin $\alpha_{\mathrm{v}}$ siRNA (Graef et al. 2005) (Dharmacon) were transfected with Lipofectamine 2000 (Invitrogen Corp.) according to the manufacturer's instructions. After $6 \mathrm{~h}$ of incubation, fresh medium was added to the cells. Forty-eight hours after transfection, TEM and FACS analysis were performed.

\section{Immunofluorescence microscopy}

Monolayer HUVECs were incubated with an anti-VE-cadherin antibody, BV9 (Abcam; 1:20 in EGM-2 medium) for 20 min at room temperature and washed with PBS three times. Cells were then fixed with $4 \%$ paraformaldehyde followed by PBS washes. After blocking with $2.5 \%$ normal goat serum, cells were incubated with secondary antibody for $45 \mathrm{~min}$. Following three PBS washes, the cells were stained with Hoechst (Sigma). Samples were visualized on a Zeiss LSM410 confocal microscope.

\section{Vascular permeability assay}

HUVEC cells $\left(2.7 \times 10^{4}\right)$ were seeded on fibronectin-coated Transwell filters $(0.4-\mu \mathrm{m}$ pore size; Costar) in 24-well plates and cultured with $100 \mu \mathrm{L}$ of EGM-2 media in the upper chamber and $600 \mu \mathrm{L}$ in the lower chamber. The cells were grown for $3 \mathrm{~d}$ without medium change until they had reached confluence. For the assay, $100 \mu \mathrm{L}$ of the indicated conditioned media with $4 \mu \mathrm{L}$ of FITC-dextran ( $\mathrm{Mr} 4 \times 10^{4}$; Sigma; final concentration $1 \mathrm{mg} /$ $\mathrm{mL}$ ) were added to the upper chamber. At the indicated time points, $50-\mu \mathrm{L}$ samples were taken from the lower chamber and replaced immediately with the same volume of growth medium to maintain hydrostatic equilibrium. The samples were diluted to $1 \mathrm{~mL}$ with PBS, and the fluorescent content was measured at 492/520 nm absorption/emission wavelengths for FITC-dextran. For the peptide blockade and Src inhibitor pretreatment assays, the endothelial monolayer was pretreated with peptides or Src inhibitor PP1 at the indicated concentration for $1 \mathrm{~h}$ before FITC-dextran and conditioned media were added. The fluorescent content in the lower chamber was measured $4 \mathrm{~h}$ later.

\section{Cell survival assay under hypoxia condition}

$\beta$ ig-h3-producing and vector-control SW480 cells were grown in the normal media until $60 \%-70 \%$ confluency. Then, they were treated with $100 \mu \mathrm{M}$ DFO (Deferoxamine; Sigma) to mimic hypoxia (Bianchi et al. 1999) for different time points as indicated, and the numbers of surviving cells at different time points were analyzed and counted. The results were quantified from three independent experiments.

\section{Anoikis assay}

To determine the effect of $\beta i g-h 3$ on cell survival under an anoikis-inducing condition, cells were prevented from adhering by culturing them in Petri dishes coated with PolyHema (Sigma) as described previously (Bao et al. 2004). Subconfluent $\beta$ ig-h3-producing or the vector-control SW480 cells were trypsinized, washed, and transferred to the PolyHema-coated Petri dishes in the serum-free media and then incubated for different time points as indicated. Apoptotic cells from PolyHema-coated dishes were checked and analyzed using the Annexin V Apoptosis Detection Kit (BD Pharmingen).

\section{Acknowledgments}

We thank Drs. C. Counter, A.P. Pendergast, and X. Guo for critical comments on the manuscript, and Y. Yu for technical support. This work was supported by NIH grants DK064113 and CA122998 (to X.W.).

\section{References}

Allinen, M., Beroukhim, R., Cai, L., Brennan, C., Lahti-Domenici, J., Huang, H., Porter, D., Hu, M., Chin, L., Richardson, A., et al. 2004. Molecular characterization of the tumor microenvironment in breast cancer. Cancer Cell 6: 17-32.

Allport, J.R., Ding, H., Collins, T., Gerritsen, M.E., and Luscinskas, F.W. 1997. Endothelial-dependent mechanisms regulate leukocyte transmigration: A process involving the proteasome and disruption of the vascular endothelial-cadherin complex at endothelial cell-to-cell junctions. J. Exp. Med. 186: $517-527$.

Argani, P., Rosty, C., Reiter, R.E., Wilentz, R.E., Murugesan, S.R., Leach, S.D., Ryu, B., Skinner, H.G., Goggins, M., Jaffee, 
E.M., et al. 2001. Discovery of new markers of cancer through serial analysis of gene expression: Prostate stem cell antigen is overexpressed in pancreatic adenocarcinoma. Cancer Res. 61: 4320-4324.

Bae, J.S., Lee, S.H., Kim, J.E., Choi, J.Y., Park, R.W., Yong Park, J., Park, H.S., Sohn, Y.S., Lee, D.S., Bae Lee, E., et al. 2002. $\beta$ ig-h3 supports keratinocyte adhesion, migration, and proliferation through $\alpha 3 \beta 1$ integrin. Biochem. Biophys. Res. Commun. 294: 940-948.

Bao, S., Ouyang, G., Bai, X., Huang, Z., Ma, C., Liu, M., Shao, R., Anderson, R.M., Rich, J.N., and Wang, X.F. 2004. Periostin potently promotes metastatic growth of colon cancer by augmenting cell survival via the Akt/PKB pathway. Cancer Cell 5: 329-339.

Bastiani, M.J., Harrelson, A.L., Snow, P.M., and Goodman, C.S. 1987. Expression of fasciclin I and II glycoproteins on subsets of axon pathways during neuronal development in the grasshopper. Cell 48: 745-755.

Bernstein, L.R. and Liotta, L.A. 1994. Molecular mediators of interactions with extracellular matrix components in metastasis and angiogenesis. Curr. Opin. Oncol. 6: 106-113.

Bhowmick, N.A., Neilson, E.G., and Moses, H.L. 2004. Stromal fibroblasts in cancer initiation and progression. Nature 432: 332-337.

Bianchi, L., Tacchini, L., and Cairo, G. 1999. HIF-1-mediated activation of transferrin receptor gene transcription by iron chelation. Nucleic Acids Res. 27: 4223-4227.

Bierie, B. and Moses, H.L. 2006. Tumour microenvironment: TGFß: The molecular Jekyll and Hyde of cancer. Nat. Rev. Cancer 6: 506-520.

Brummelkamp, T.R., Bernards, R., and Agami, R. 2002. Stable suppression of tumorigenicity by virus-mediated RNA interference. Cancer Cell 2: 243-247.

Buckhaults, P., Rago, C., St Croix, B., Romans, K.E., Saha, S., Zhang, L., Vogelstein, B., and Kinzler, K.W. 2001. Secreted and cell surface genes expressed in benign and malignant colorectal tumors. Cancer Res. 61: 6996-7001.

Chambers, A.F., Groom, A.C., and MacDonald, I.C. 2002. Dissemination and growth of cancer cells in metastatic sites. Nat. Rev. Cancer 2: 563-572.

Cooper, C.R., Chay, C.H., Gendernalik, J.D., Lee, H.L., Bhatia, J., Taichman, R.S., McCauley, L.K., Keller, E.T., and Pienta, K.J. 2003. Stromal factors involved in prostate carcinoma metastasis to bone. Cancer 97 (Suppl. 3): 739-747.

Delannet, M., Martin, F., Bossy, B., Cheresh, D.A., Reichardt, L.F., and Duband, J.L. 1994. Specific roles of the $\alpha_{V} \beta_{1}, \alpha_{V} \beta_{3}$ and $\alpha_{\mathrm{v}} \beta_{5}$ integrins in avian neural crest cell adhesion and migration on vitronectin. Development 120: 2687-2702.

Ferguson, J.W., Thoma, B.S., Mikesh, M.F., Kramer, R.H., Bennett, K.L., Purchio, A., Bellard, B.J., and LeBaron, R.G. 2003. The extracellular matrix protein $\beta$ IG-H3 is expressed at myotendinous junctions and supports muscle cell adhesion. Cell Tissue Res. 313: 93-105.

Gomis, R.R., Alarcon, C., Nadal, C., Van Poznak, C., and Massague, J. 2006. C/EBP $\beta$ at the core of the TGF $\beta$ cytostatic response and its evasion in metastatic breast cancer cells. Cancer Cell 10: 203-214.

Graef, T., Steidl, U., Nedbal, W., Rohr, U., Fenk, R., Haas, R., and Kronenwett, R. 2005. Use of RNA interference to inhibit integrin subunit $\alpha_{\mathrm{V}}$-mediated angiogenesis. Angiogenesis 8: 361-372.

Grum-Schwensen, B., Klingelhofer, J., Berg, C.H., El-Naaman, C., Grigorian, M., Lukanidin, E., and Ambartsumian, N. 2005. Suppression of tumor development and metastasis formation in mice lacking the S100A4(mts1) gene. Cancer Res. 65: 3772-3780.
Gupta, G.P., Nguyen, D.X., Chiang, A.C., Bos, P.D., Kim, J.Y., Nadal, C., Gomis, R.R., Manova-Todorova, K., and Massague, J. 2007. Mediators of vascular remodelling co-opted for sequential steps in lung metastasis. Nature 446: 765-770.

Hanahan, D. and Weinberg, R.A. 2000. The hallmarks of cancer. Cell 100: 57-70.

Hewitt, R.E., McMarlin, A., Kleiner, D., Wersto, R., Martin, P., Tsokos, M., Stamp, G.W., and Stetler-Stevenson, W.G. 2000. Validation of a model of colon cancer progression. J. Pathol. 192: 446-454.

Horiuchi, K., Amizuka, N., Takeshita, S., Takamatsu, H., Katsuura, M., Ozawa, H., Toyama, Y., Bonewald, L.F., and Kudo, A. 1999. Identification and characterization of a novel protein, periostin, with restricted expression to periosteum and periodontal ligament and increased expression by transforming growth factor $\beta$. J. Bone Miner. Res. 14: 1239-1249.

Hunter, T. 1987. A tail of two src's: Mutatis mutandis. Cell 49: $1-4$.

Kang, Y., He, W., Tulley, S., Gupta, G.P., Serganova, I., Chen, C.R., Manova-Todorova, K., Blasberg, R., Gerald, W.L., and Massague, J. 2005. Breast cancer bone metastasis mediated by the Smad tumor suppressor pathway. Proc. Natl. Acad. Sci. 102: 13909-13914.

Karnoub, A.E., Dash, A.B., Vo, A.P., Sullivan, A., Brooks, M.W., Bell, G.W., Richardson, A.L., Polyak, K., Tubo, R., and Weinberg, R.A. 2007. Mesenchymal stem cells within tumour stroma promote breast cancer metastasis. Nature 449: 557563.

Kim, M.O., Yun, S.J., Kim, I.S., Sohn, S., and Lee, E.H. 2003. Transforming growth factor- $\beta$-inducible gene-h3 ( $\beta(\mathrm{ig})-\mathrm{h} 3$ ) promotes cell adhesion of human astrocytoma cells in vitro: Implication of $\alpha 6 \beta 4$ integrin. Neurosci. Lett. 336: 93-96.

Lampugnani, M.G., Resnati, M., Raiteri, M., Pigott, R., Pisacane, A., Houen, G., Ruco, L.P., and Dejana, E. 1992. A novel endothelial-specific membrane protein is a marker of cell-cell contacts. J. Cell Biol. 118: 1511-1522.

LeBaron, R.G., Bezverkov, K.I., Zimber, M.P., Pavelec, R., Skonier, J., and Purchio, A.F. 1995. $\beta$ IG-H3, a novel secretory protein inducible by transforming growth factor- $\beta$, is present in normal skin and promotes the adhesion and spreading of dermal fibroblasts in vitro. J. Invest. Dermatol. 104: 844-849.

Lee, B.H., Bae, J.S., Park, R.W., Kim, J.E., Park, J.Y., and Kim, I.S. 2006. $\beta$ ig-h3 triggers signaling pathways mediating adhesion and migration of vascular smooth muscle cells through $\alpha \mathrm{v} \beta 5$ integrin. Exp. Mol. Med. 38: 153-161.

Leibovitz, A., Stinson, J.C., McCombs III, W.B., McCoy, C.E., Mazur, K.C., and Mabry, N.D. 1976. Classification of human colorectal adenocarcinoma cell lines. Cancer Res. 36: 45624569.

MacDonald, I.C., Groom, A.C., and Chambers, A.F. 2002. Cancer spread and micrometastasis development: Quantitative approaches for in vivo models. Bioessays 24: 885-893.

Morgenstern, J.P. and Land, H. 1990. Advanced mammalian gene transfer: High titre retroviral vectors with multiple drug selection markers and a complementary helper-free packaging cell line. Nucleic Acids Res. 18: 3587-3596.

Mueller, M.M. and Fusenig, N.E. 2004. Friends or foes-Bipolar effects of the tumour stroma in cancer. Nat. Rev. Cancer 4: 839-849.

Nam, J.O., Kim, J.E., Jeong, H.W., Lee, S.J., Lee, B.H., Choi, J.Y., Park, R.W., Park, J.Y., and Kim, I.S. 2003. Identification of the $\alpha v \beta 3$ integrin-interacting motif of $\beta i g-h 3$ and its antiangiogenic effect. J. Biol. Chem. 278: 25902-25909.

O'Brien, E.R., Bennett, K.L., Garvin, M.R., Zderic, T.W., Hinohara, T., Simpson, J.B., Kimura, T., Nobuyoshi, M., Mizgala, 
H., Purchio, A., et al. 1996. $\beta$ ig-h3, a transforming growth factor- $\beta$-inducible gene, is overexpressed in atherosclerotic and restenotic human vascular lesions. Arterioscler. Thromb. Vasc. Biol. 16: 576-584.

Orimo, A. and Weinberg, R.A. 2006. Stromal fibroblasts in cancer: A novel tumor-promoting cell type. Cell Cycle 5: 15971601.

Orimo, A., Gupta, P.B., Sgroi, D.C., Arenzana-Seisdedos, F., Delaunay, T., Naeem, R., Carey, V.J., Richardson, A.L., and Weinberg, R.A. 2005. Stromal fibroblasts present in invasive human breast carcinomas promote tumor growth and angiogenesis through elevated SDF-1/CXCL12 secretion. Cell 121: 335-348.

Reed, J., Ouban, A., Schickor, F.K., Muraca, P., Yeatman, T., and Coppola, D. 2002. Immunohistochemical staining for c-Kit (CD117) is a rare event in human colorectal carcinoma. Clin. Colorectal Cancer 2: 119-122.

Sandig, M., Voura, E.B., Kalnins, V.I., and Siu, C.H. 1997. Role of cadherins in the transendothelial migration of melanoma cells in culture. Cell Motil. Cytoskeleton 38: 351-364.

Schneider, D., Kleeff, J., Berberat, P.O., Zhu, Z., Korc, M., Friess, H., and Buchler, M.W. 2002. Induction and expression of Big-h3 in pancreatic cancer cells. Biochim. Biophys. Acta 1588: $1-6$.

Schweitzer, C.M., van der Schoot, C.E., Drager, A.M., van der Valk, P., Zevenbergen, A., Hooibrink, B., Westra, A.H., and Langenhuijsen, M.M. 1995. Isolation and culture of human bone marrow endothelial cells. Exp. Hematol. 23: 41-48.

Shao, R., Bao, S., Bai, X., Blanchette, C., Anderson, R.M., Dang, T., Gishizky, M.L., Marks, J.R., and Wang, X.F. 2004. Acquired expression of periostin by human breast cancers promotes tumor angiogenesis through up-regulation of vascular endothelial growth factor receptor 2 expression. Mol. Cell. Biol. 24: 3992-4003.

Shipitsin, M., Campbell, L.L., Argani, P., Weremowicz, S., Bloushtain-Qimron, N., Yao, J., Nikolskaya, T., Serebryiskaya, T., Beroukhim, R., Hu, M., et al. 2007. Molecular definition of breast tumor heterogeneity. Cancer Cell 11: 259-273.

Skonier, J., Neubauer, M., Madisen, L., Bennett, K., Plowman, G.D., and Purchio, A.F. 1992. cDNA cloning and sequence analysis of $\beta i g-h 3$, a novel gene induced in a human adenocarcinoma cell line after treatment with transforming growth factor- $\beta$. DNA Cell Biol. 11: 511-522.

Su, G., Hodnett, M., Wu, N., Atakilit, A., Kosinski, C., Godzich, M., Huang, X.Z., Kim, J.K., Frank, J.A., Matthay, M.A., et al. 2006. Integrin $\alpha_{\mathrm{v}} \beta_{5}$ regulates lung vascular permeability and pulmonary endothelial barrier function. Am. J. Respir. Cell Mol. Biol. 10: 10-11.

Tremblay, P.L., Auger, F.A., and Huot, J. 2006. Regulation of transendothelial migration of colon cancer cells by E-selectin-mediated activation of p38 and ERK MAP kinases. Oncogene 25: 6563-6573.

Vestweber, D. 2002. Regulation of endothelial cell contacts during leukocyte extravasation. Curr. Opin. Cell Biol. 14: 587593.

Voura, E.B., Ramjeesingh, R.A., Montgomery, A.M., and Siu, C.H. 2001. Involvement of integrin $\alpha_{v} \beta_{3}$ and cell adhesion molecule L1 in transendothelial migration of melanoma cells. Mol. Biol. Cell 12: 2699-2710.

Weerasinghe, D., McHugh, K.P., Ross, F.P., Brown, E.J., Gisler, R.H., and Imhof, B.A. 1998. A role for the $\alpha_{\mathrm{v}} \beta_{3}$ integrin in the transmigration of monocytes. J. Cell Biol. 142: 595-607.

Weis, S.M. and Cheresh, D.A. 2005. Pathophysiological consequences of VEGF-induced vascular permeability. Nature 437: 497-504.
Weis, S., Cui, J., Barnes, L., and Cheresh, D. 2004. Endothelial barrier disruption by VEGF-mediated Src activity potentiates tumor cell extravasation and metastasis. J. Cell Biol. 167: 223-229.

Weiss, L. 1990. Metastatic inefficiency. Adv. Cancer Res. 54: 159-211.

Woodhouse, E.C., Chuaqui, R.F., and Liotta, L.A. 1997. General mechanisms of metastasis. Cancer 80 (Suppl. 8): 1529-1537.

Yin, J.J., Selander, K., Chirgwin, J.M., Dallas, M., Grubbs, B.G., Wieser, R., Massague, J., Mundy, G.R., and Guise, T.A. 1999. TGF- $\beta$ signaling blockade inhibits PTHrP secretion by breast cancer cells and bone metastases development. J. Clin. Invest. 103: 197-206.

Zhang, L., Zhou, W., Velculescu, V.E., Kern, S.E., Hruban, R.H., Hamilton, S.R., Vogelstein, B., and Kinzler, K.W. 1997. Gene expression profiles in normal and cancer cells. Science 276: $1268-1272$. 


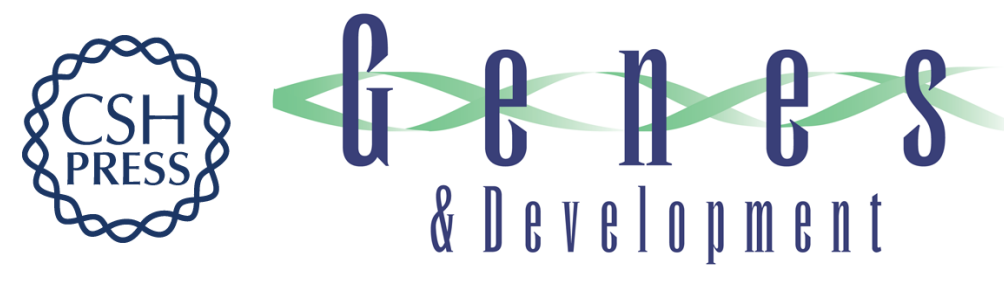

\section{Extracellular matrix protein $\beta$ ig-h3/TGFBI promotes metastasis of colon cancer by enhancing cell extravasation}

Chaoyu Ma, Yu Rong, Daniel R. Radiloff, et al.

Genes Dev. 2008, 22:

Access the most recent version at doi:10.1101/gad.1632008

Supplemental http://genesdev.cshlp.org/content/suppl/2008/01/16/22.3.308.DC1
Material

References This article cites 56 articles, 15 of which can be accessed free at:

http://genesdev.cshlp.org/content/22/3/308.full.html\#ref-list-1

License

Email Alerting Receive free email alerts when new articles cite this article - sign up in the box at the top

Service right corner of the article or click here.

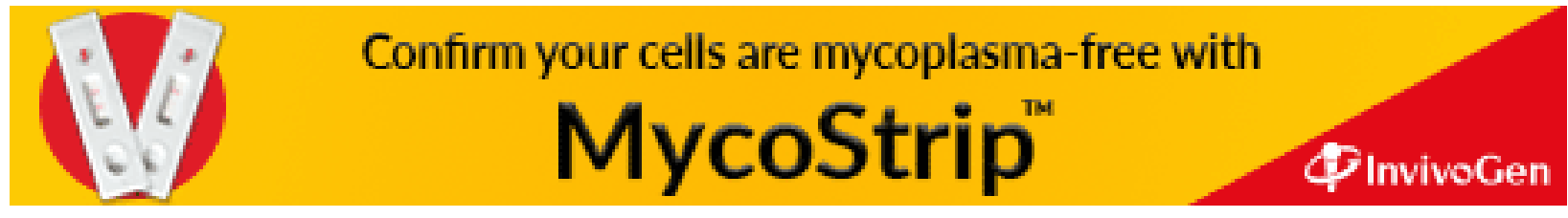

